\title{
Pengaruh Sistem Pengendalian Internal Pemerintah Desa, Kompetensi Sumber Daya Manusia, dan Efektivitas Sistem Keuangan Desa Terhadap Penerapan Good Village Governance
}

\author{
Ni Wayan Desi Sawitri ${ }^{1}$, Lucy Sri Musmini² \\ 1,2 Program Studi S1 Akuntansi, Universitas Pendidikan Ganesha \\ Singaraja, Indonesia \\ e-mail: 1 desisawitri69@gmail.com, ${ }^{2} \mid$ lucy.musmini@gmail.com
}

\begin{abstract}
Abstrak
Penelitian ini bertujuan untuk memahami pengaruh sistem pengendalian internal pemerintah desa, kompetensi sumber daya manusia dan efektivitas sistem keuangan desa terhadap penerapan good village governance pada desa di Kabupaten Buleleng. Jenis riset ini adalah riset kuantitatif dengan menggunakan data yang didapat dari kuesioner dan diukur menggunakan skala likert. Populasi dalam riset ini yaitu semua desa di Kabupaten Buleleng dengan total populasi yaitu 129 desa. Pengambilan sampel dalam riset ini menggunakan teknik probability sampling dengan menggunakan sampel sebanyak 56 desa dan responden sebanyak 168 orang. Metode yang digunakan dalam menganalisis data yaitu analisis regresi linear berganda menggunakan SPSS versi 20.0. Capaian dalam riset ini memperlihatkan bahwa sistem pengendalian internal pemerintah desa kompetensi sumber daya manusia dan efektivitas sistem keuangan desa berpengaruh positif dan signifikan terhadap penerapan good village governance.
\end{abstract}

Kata kunci: Good Village Governance, sistem pengendalian internal pemerintah desa, kompetensi sumber daya manusia, efektivitas sistem keuangan desa.

\begin{abstract}
This research aims to determine the effect to the village government's internal control system, human resource competencies and the effecttiveness of the village financial system on the implementation of good village governance in villages in Buleleng Regency. The type of the research is quantitative research. The populatian in thid research is all villages in Buleleng Regency, namely 129 villages. Sampling in this research used probability sampling techniques using a sample of 56 villages and 168 respondents. In this research data were obtained through a questionnaire distributed directly to respondents. Data analysis in this research uses multiple linear regression analysis with the help of SPSS version 20.0. The results this research stated that the internal control system of villages government, human resource competency, and effectiveness of the village financial system had a positive and significant effect on the implementation of good village governance.
\end{abstract}

Keywords : good village governance, village government control system, human resource competence, effectiveness of the village financial system.

\section{Pendahuluan}

Penyelenggaraan pemerintahan di Indonesia menerapkan sistem desentralisasi. Pemerintah daerah akan diberikan kebebasan dan kesempatan untuk menyelenggarakan otonomi daerah. Moch (2012) mengungkapkan bahwa pemerintah daerah memiliki peluang yang besar dalam mendorong demokratisasi karena dengan asas desentralisasi lebih memungkinkan terwujudnya pemerintahan yang responsif, partisipatif, dan akuntabel. Pemerintah telah menerbitkan Undang-undang Nomor 32 Tahun 2004 yang berhubungan dengan pemerintah daerah yang memberikan peluang kepada masyarakat agar berperan aktiifndalam penyelenggaraan pemerintahan, baik dalam pemerintahan pusat, pemerintahan daerah, maupun pemerintahan desa. 
Penyelenggaraan pemerintahan pada tingkat desa tidak terlepas dari upaya dalam menerapkan good vilage goverrnance. Good village governance adalah wujud implementasi dari prinsip dasar good governance dalam penyelenggraan pemerintahan desa. Terdapat tiga kompenen yang saling bekaitan antarkomponen dalam mengimplementasikan good village governance yaitu, transparansi, akuntabilitas, partisipasi. Transparansi sangat diperlukan dalam penyelenggaraan pemerintah desa sebagai wujud pertangungjawaban atas semua kebijakan dan keputusan yang sudah disepekati dan telah dilaksanaan. Selain itu dibutuhkannya transparansi dalam upaya meningkatkan partiisipasi dari masyarakat untuk ikut membangun dan ikut serta memberi masukan, serta ikut serta mengontrol jalannya pelaksanaan pemerintahan desa.dari Kalau ketiga komponen tersebut bisa diaplikasikan dengan baik, maka good village goverrnance dapat tercapai.

Pemerintah desa memiliki wewenang untuk mengatur tata pemerintahannya sendiri. Penyelenggara pemerintahan desa adalah kepala desa dan perangkat desa. Merujuk pada Undang-undang Nomor 6 Tahun 2014 mengenai Desa, disebutkan bahwa kepala desa memiliki tanggungjawab untuk menyelenggarakan tata pemerintahan yang akuntabel, transparan, profesional, efektif dan efisien, bersih, serta bebas dari kolusi, korupsi dan nepotiisme. Desa mendapatkan dana desa yang berasal dari APBN untuk menyelenggarakan pemerintahan desa. Dalam APBN 2020 telah tercatat dana sebesar Rp 72 triliun akan dialokasikan untuk 74.953 desa yang tersebar di seluruh Indonesia (djpk. kemenkeu.go.id). Dengan begitu besarnya dana desa yang dialokasikan ke masing-masing desa, maka akan semakin besar pula tanggung jawab aparatur desa dalam mengelola dana desa. Dana yang diterima oleh desa harus dikelola dengan baik oleh aparat desa agar pelaksanaanya tepat sasaran. Oleh karena itu, perlu adanya pengawasan dalam pelaksanaanya. Hal dilakukan untuk mengurangi terjadinya resiko penyalahgunaan pengelolaan anggaran dana desa yang dilakukan oleh pihak-pihak terkait. Faktor-faktor yang mendukung penerapan good village governance yaitu sistem pengendalian internal pemerintah desa, kompetensi sumber daya manusia, dan efektivitas sistem keuangan desa.

Merujuk pada Peraturan Pemerintah Nomor 8 Tahun 2006, dijelaskan sistem pengendalian internal sebagai sebuah proses dalam upaya memberikan keyakinan untuk mencapai efektivitas, efisiensi, kepatuhan terhadap peraturan perundang-undangan yang berlaku terhadap keandalan laporan keuangan pemerintah. Sistem pengendalian yang diberlakukan secara menyeluruh pada lingkungan pemerintah desa merupakan definsi dari sistem pengendalian internal pemerintah desa (Prawira, 2014). Sistem pengendalian internal pemerintah desa yang baik akan dapat mengendalikan penyelenggaraan kegiatan desa dan dapat meminimalisir terjadinya kesalahan dan penyimpangan dalam pengelolaan keuangan penyelenggaraan pemerintahan desa. Hasil riset dari Mailoor (2017) menjelaskan bahwa sistem pengendalian internal pemerintah berpengaruh positif terhadap penerapan good governance. Hasil riset Kamaru (2016) menjelaskan sistem pengendalian internal berpengaruh positif terhadap penerapan good governance. Bersumber dari konsep teori dan hasil riset terdahulu, hipotesis pertama yang digunakan pada riset ini yaitu:

$\mathrm{H}_{1}$ : Sistem pengendalian internal pemerintah desa berpengaruh terhadap penerapan good village governance.

Kompetensi sumber daya manusia merupakan kemampuan, keterampilan dan pengetahuan yang melekat pada individu dalam rangka melaksanakan tugas dan fungsinya secara efektif dan efisien (Ishanti, 2014). Kompetensi sumber daya manusia berperan penting dalam pemerintahan desa. Sumber daya manusia yang kompeten sangat diperlukan dalam pemerintah desa untuk mendukung pengelolaan keuangan desa agar pengelolaan keuangan desa dapat dialokasikan dengan benar, tepat waktu dan dapat dipertangungjawabkan secara transparan dan akuntabel. Hasil riset Helmayani (2017) menjelaskann bahwa kompetensi sumber daya manusia berpengaruh positif dan signifiikan terhadap implementasi good village governance. Berdasarkan pemaparan diatas, hipotesis kedua yang digunakan dalam riset ini yaitu:

$\mathrm{H}_{2}$ : Kompetensi sumber daya manusia berpengaruh terhadap penerapan good village governance. 
Sistem keuangan desa adalah sebuah aplikasi yang dirancang oleh BPKP bersama Kemendagri guna meningkatkan kualitas tata kelola keuangan desa. Sistem keuangan desa ini sangat diperlukan dalam pengelolaan keuangan desa, dengan adanya sistem keuangan desa memberikan dampak kepada pemerintah desa, yaitu memberikan motivasi bagi pemerintah desa untuk bekerja dengan baik dan benar, kegiatan operasional pemerintah desa menjadi lebih tertata secara administratif, meningkatkan kinerja aparatur pemerintah desa, mengurangi adanya kesalahan dan kecurangan, pengelolaan keuangan desa menjadi tepat sasaran, dan dapat menciptakan laporan keuangan yang akuntabel (Sulina, 2017). Hasil riset Krisnawati (2019) menjelaskan bahwa efektivitas sistem keuangan desa berpengaruh positif dan signifikan terhadap kinerja pemerintah desa. Hasil riset Saputri (2019) menunjukkan bahwa sistem keuangan desa berpengaruh terhadap good village governance. Berdasarkan pemaparan diatas, hipotesis ketiga yang digunakan dalam riset ini yaitu:

$\mathrm{H}_{3}$ : Efektivitas Sistem Keuangan Desa berpengaruh terhadap Penerapan Good Village Governance.

\section{Metode}

Pendekatan yang digunakan dalam riset ini adalah pendekatan kuantitaif dengan data primer yang berasal dari kuesioner yang distribusikan kepada responden dan diukur dengan menggunakan skala likert serta dianalisis dengan menggunakan program SPSS versi 20.0 Riset ini dilakukan di Kabupaten Buleleng dengan jumlah populasi sebanyak 129 desa yang tersebar di 9 kecamatan yang berada Kabupaten Buleleng. Dalam riset ini menggunakan teknik probability sampling (simple random sampling), dimana sampel dipilih secara acak tanpa memperhatikan tingkatan yang ada dalam populasi itu sendiri (Sugiyono, 2013). Dari hasil perhitungan rumus slovin, total sampel pada riset ini adalah 56 desa dengan 3 responden pada masing-masing desa yang meliputi kepala desa, sekretaris desa, dan kaur keuangan sehingga total responden riset ini adalah 168 responden.

Instrumen dalam riset ini berbentuk kuesiioner yang didistribusikan kepada 168 responden. Dalam menguji instrumen dilakukan beberapa pengujian seperi uji satistik deskriptif, uji validitas, dan uji reabilitas. Dalam penganalisisan data dalam riset ini meliputi uji normalitas, uji multikolinearitas, uji heteroskedastisitas. Untuk menguji hipotesis dengan analisis regresi linear berganda, uji koefisien determinasi dan uji t.

\section{Hasil Dan Pembahasan}

Hasil riset ini meliputi uji statistik deskriptif, uji kualitas data, uji asumsi klasik, dan uji hipotesis. Analisis statistik deskriptif digunakan untuk mengetahui nilai minimal, maksimal, rata-rata dan standar deviiasi. Berdasarkan hasil uji statistik deskriptif dari 168 responden, Variabel Sistem Pengendalian Internal Pemerintah Desa $\left(X_{1}\right)$ memiliki nilai minimal 75 , nilai maksimal 95, nilai rata-rata 84,63, dan standar deviasi 5,167. Hal ini menunujukkan bahwa dari 20 item pertanyaan mengenai Sistem Pengendalian Internal Pemerintah Desa $\left(X_{1}\right)$, diperoleh rata-rata jawaban responden adalah 4 atau setuju. Variabel Kompetensi Sumber Daya Manusia $\left(X_{2}\right)$ mempunyai nilai minimal 75 , nilai maksimal 95, nilai rata-rata 88,35, dan standar deviasi 3,303. Hal ini menunujukkan bahwa dari 20 item pertanyaan mengenai Kompetensi Sumber Daya Manusia $\left(X_{2}\right)$, diperoleh rata-rata jawaban responden adalah 4 atau setuju. Variabel Efektivitas Sistem Keuangan Desa $\left(X_{3}\right)$ mempunyai nilai minimal 16 , nilai maksimal 25 , nilai rata-rata 21,81, dan standar deviasi 2,186. Hal ini menunujukkan bahwa dari 5 item pertanyaan mengenai Efektivitas Sistem Keuangan Desa $\left(\mathrm{X}_{3}\right)$, diperoleh rata-rata jawaban responden adalah 4 atau setuju. Variabel Penerapan Good Village Governance $(Y)$ memiliki nilai minimal 42, nilai maksimal 60, nilai rata-rata 53,51, dan nilai standar deviasi r 4,692. Hal ini menunjukkan bahwa dari 12 item pertanyaan mengenai Penerapan Good Village Governance $(\mathrm{Y})$, diperoleh rata-rata jawaban responden adalah 5 atau sangat setuju.

Tabel 1. Hasil Uji Statistik Deskripstif 


\begin{tabular}{lccccc}
\hline \multicolumn{1}{c}{ Variabel Penelitian } & N & Minimum & Maximum & Mean & $\begin{array}{c}\text { Std. } \\
\text { Deviation }\end{array}$ \\
\hline $\begin{array}{l}\text { Sistem Pengendalian } \\
\text { Internal Pemerintah Desa }\end{array}$ & 168 & 75 & 95 & 84,63 & 5,167 \\
$\begin{array}{l}\text { Kompetensi Sumber Daya } \\
\text { Manusia }\end{array}$ & 168 & 75 & 95 & 88,35 & 3,303 \\
$\begin{array}{l}\text { Efektifitas Sistem } \\
\text { Keuangan Desa }\end{array}$ & 168 & 16 & 25 & 21,81 & 2,186 \\
$\begin{array}{l}\text { Penerapan Good Village } \\
\text { Governance }\end{array}$ & 168 & 42 & 60 & 52,51 & 4,692 \\
\hline
\end{tabular}

Tahap awal pengujian instrumen adalah uji kualitas data yang melibatkan uji validitas dan uji reliabilitas. Dalam mengukur valid atau tidaknya suatu instrumen dilakukan uji validitas. Kriteria instrumen dikatakan valid jika menghasilkan $r_{\text {hitung }}>r_{\text {tabel }}$ (Sugiyono, 2013). Berdasarkan uji validitas data yang telah dilakukan menunjukkan bahwa semua butir pertanyaan pada setiap variabel memiliki nilai $r_{\text {hitung }}>r_{\text {tabel }}\left(r_{\text {tabel }}=0,151\right.$, pada $\left.N=168\right)$. Artinya bahwa keseluruhan butir pertanyaan pada setiap variabel dikatakan valid. Selanjutnya adalah uji reliabilitas. Reliabel dapat didefinisikan sebagai suatu instrumen yang telah beberapa kali dipergunakan dalam mengukur suatu objek yang sama dan tetap menghasilkan output yang sama Butir pertanyaan dinyatakan reliabel jika mempunyai nilai Alpha Cronnbach > 0,70 (Sugiyono, 2013). Capaian uji reliabilitas memperlihatkan bahwa keseluruhan variabel memiliki nilai Alpha Cronbach $>0,70$. Hal ini berarti bahwa keseluruhan butir pertanyaan pada setiap variabel dinyatakan reliabel.

\begin{tabular}{llr} 
Tabel 2. Hasil Uji Normalitas Data One-Sample-Kolmogorov-Smirnov Test \\
& & $\begin{array}{c}\text { Unstandarized } \\
\text { Residual }\end{array}$ \\
\hline $\mathrm{N}$ & Mean & 168 \\
Normal Parameters & \\
& Std.Deviation & .0000000 \\
Most Extreme & Absolute & 2.64326015 \\
Difference & Positive & .053 \\
& Negative & .053 \\
Kolmogorov-Smirnov Z & & -.029 \\
Asymp. Sig. (2-tailed) & & .690 \\
\hline
\end{tabular}

Setelah uji kualitas data terpenuhi dilanjutkan dengan uji asumsi klasik yang meliputi uji normalitas, uji multikolinearitas, dan uji heteroskedastisitas. Uji asumsi klasik yang pertama adalah uji normalitas yang dilakukan guna menguji suatu data berdistribusi normal atau tidak, dengan mempergunakan metode One Sampel Kolmogorov-Smirnov. Apabila nilai signifikansi lebih besar dari 0,05, maka data dikatakan berdistribusi normal. Merujuk pada hasil uji normalitas menggunakan Kolmogorov-Smirnov menghasilkan nilai signifikan Kolmogorov-Smirnov 0,727. Capaian ini mengindikasikan bahwa ukuran signifikansi 0,727 lebih besar dari 0,05, maka kesimpulannya adalah populasi berdistribusi normal.

Selanjutnya adalah uji multikolineraitas yang berguna untuk mengetahui adanya hubungan antarvariabel independen. Untuk mendeteksi adanya multikolinearitas dapat dilihat melalui nilai Variance Inflation Factor (VIF) dan nilai tolerance. Sebuah model regresi dinyatakan bebas gejala multikolinearitas jika memiliki VIF $<10$ dan nilai tolerance $>0,1$. 


\begin{tabular}{|c|c|c|c|}
\hline \multirow{2}{*}{ Variabel Penelitian } & \multicolumn{2}{|c|}{ Colleniarity Statistic } & \multirow{2}{*}{ Keterangan } \\
\hline & Tolerance & VIF & \\
\hline $\begin{array}{l}\text { Sistem Pengendalian Internal } \\
\text { Pemerintah Desa } \\
\text { Kompetensi Sumber Daya }\end{array}$ & 0.614 & 1,561 & Bebas Multikolineritas \\
\hline $\begin{array}{l}\text { Manusia } \\
\text { Efektifitas Sistem Keuangan }\end{array}$ & 0.811 & 1,234 & Bebas Multikolineritas \\
\hline Desa & 0,659 & 1,517 & Bebas Multikolineritas \\
\hline
\end{tabular}

Capaian uji multikolinearitas diatas mengindikasikan bahwa seluruh variabel independen memiliki nilai tolerance lebih besar dari 0,1 dan nilai VIF lebih kecil dari 10. Hal ini menunjukkan bahwa semua variabel independen dalam riset ini bebas dari gejela multikolineariitas. Artinya tidak ada korelasi antara variabel independen.

Uji asumsi klasiik berikutnya yaitu uji heteroskedastiisitas yang dipergunakan untuk melihati sebuah model regresi apakah terjadi perbedaan variancee dari residual pada satu pengamatan ke pengamatan yang lainnya. Pengujian heteroskedastisitas dilaksanakan dengan menggunakan uji Glejser yang mempunyai ketentuan nilai probabilitas signifikan setiap variabel independen lebih besar dari 0,05 yang berarti bahwa tidak terjadinya gejala heteroskedastisiitas

Tabel 4. Hasil Uji Heterokedastisitas

\begin{tabular}{|c|c|c|}
\hline Variabel Penelitian & Sig. & Keterangan \\
\hline $\begin{array}{l}\text { Sistem Pengendalian Internal } \\
\text { Pemerintah Desa } \\
\text { Kompetensi Sumber Daya } \\
\text { Manusia } \\
\text { Efektifitas Sistem Keuangan } \\
\text { Desa }\end{array}$ & $\begin{array}{l}0,108 \\
0,442 \\
0,068\end{array}$ & $\begin{array}{l}\text { Tidak Terjadi } \\
\text { Heterokedastisitas } \\
\text { Tidak Terjadi } \\
\text { Heterokedastisitas } \\
\text { Tidak Terjadi } \\
\text { Heterokedastisitas }\end{array}$ \\
\hline
\end{tabular}

Merujuk pada tabel diatas, diketahui seluruh variabel memiliki nilai signiifikansi $>0,05$, artinya bahwa tidak terjadinya gejala heteroskedastisiitas. Setelah uji asumsi klasik terpenuhi, dilanjutkan dengan uji hipotesis yang meliputi analisis regresi linear berganda, uji koefisien determinasi dan uji $t$ (secara parsial). Analisis regresi linier berganda berguna untuk melihat seberapa besar pengaruh variabel independen yaitu sistem pengendalian internal pemerintah desa, kompetensi sumber daya manusiia, dan efektivitas sistem keuangan desa terhadap variabel terikat yaitu penerapan good village governance.

Bersumber dari hasil perhitungan analiisis regresi liniier pada tabel 5 diatas, maka diperoleh hasil persamaan regrresi pada riset ini yaitu:

$$
Y=-19,129+0,322 X_{1}+0.266 X_{2}+1,002 X_{3}+5,712
$$

Dari persamaan tersebut dapat diketahui nilai konstanta 19,129 menunjukkan bahwa apabila variabel independen bernilai konstant, maka variabel terikat memiliki nilai 19,129 satuan. Niilai koeffisien regresi variiabel system pengendaliian internal pemerintah desa $\left(X_{1}\right)$ adalah 0,322 , menunjukkan bahwa setiap peniingkatan system pengendaliian interrnal pemerintah desa $\left(X_{1}\right)$ satu satuan maka akan mengakibatkan peningkatan penerapan good village governance $(Y)$ sebesar 0,322 satuan, dengan angapan variabel independen lainnya dianggap konstant. Nilai koeffisien regresi kompetensi sumber daya manusia $\left(\mathrm{X}_{2}\right)$ adalah 0,266, menunjukkan bahwa setiap peningkatan kompetensi sumber daya manusia $\left(X_{2}\right)$ satu satuan maka akan menyebabkan peningkatan penerapan good village governance $(\mathrm{Y})$ sebesar 0,226 satuan, dengan anggapan variabel independen lainnya dianggap konstant. Nillai koefisiien regresi variabel efektivitas sistem keuangan desa $\left(X_{3}\right)$ adalah 1,002, menunjukkan bahwa setiap peningkatan efektivitas sistem keuangan desa $\left(X_{3}\right)$ satu satuan 
maka akan menyebabkan peningkatan penerapan good village governance $(\mathrm{Y})$ sebesar 1,002 satuan, dengan anggapan variabel independen lainnya dianggap konstant.

Tabel 5. Hasil Analisis Regresi Liner Berganda

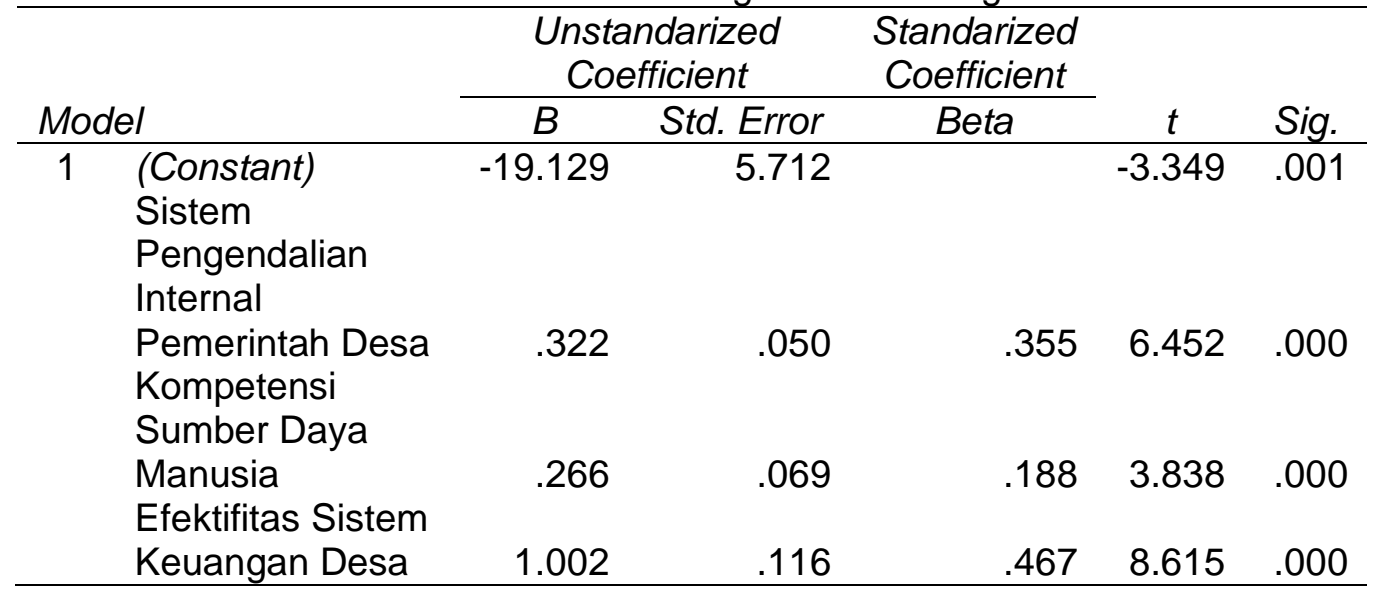

Berikutnya adalah uji koefisien determinasi yang berguna untuk mengukur besarnya pengaruh dari variabel independen $(X)$ terhadap variabel dependen $(Y)$. Nilai koefisien determinasi dapat dilihat pada Adjusted $R$ Square. Apabila nilai yang ditunjukkan pada Adjusted $R$ Square terbilang kecil artinya variabel independen memiliki kemampuan sangat terbatas saat menjelaskan variabel terikatnya

Dilihat dari tabel 6, menunjukkan luaran analisis koefisien determinasi yang ditunjukkan Adjusted $R$ Square senilai 0,677. Artinya, dalam penerapan good village governance dapat dijelaskan oleh variabel sistem pengendalian internal pemerintah desa, kompetensi sumber daya manusia, dan efektivitas sistem keuangan desa sebanyak $67,70 \%$. Sedangkan sisianya $32,30 \%$ dijelaskan oleh variabellain selain yang dimasukan pada riset ini.

Tabel 6. Hasil Uji Koefisien Determinasi

\begin{tabular}{ccccc}
\hline Model & $\mathrm{R}$ & $\mathrm{R}$ Square & $\begin{array}{c}\text { Adjusted } \mathrm{R} \\
\text { Square }\end{array}$ & $\begin{array}{c}\text { Std. Error of } \\
\text { The Estimate }\end{array}$ \\
\hline 1 & $.826^{\mathrm{a}}$ & .683 & .677 & 2.667 \\
\hline
\end{tabular}

\begin{tabular}{|c|c|c|c|c|c|c|}
\hline \multirow{2}{*}{\multicolumn{2}{|c|}{ Model }} & \multicolumn{2}{|c|}{$\begin{array}{l}\text { Unstandarized } \\
\text { Coefficient }\end{array}$} & \multirow{2}{*}{$\begin{array}{c}\text { Standarized } \\
\text { Coefficient } \\
\text { Beta }\end{array}$} & \multirow[b]{2}{*}{$t$} & \multirow[b]{2}{*}{ Sig. } \\
\hline & & $B$ & Std. Error & & & \\
\hline \multirow[t]{4}{*}{1} & $\begin{array}{l}\text { (Constant) } \\
\text { Sistem } \\
\text { Pengendalian } \\
\text { Internal }\end{array}$ & -19.129 & 5.712 & & -3.349 & .001 \\
\hline & $\begin{array}{l}\text { Pemerintah Desa } \\
\text { Kompetensi } \\
\text { Sumber Daya }\end{array}$ & .322 & .050 & .355 & 6.452 & .000 \\
\hline & $\begin{array}{l}\text { Manusia } \\
\text { Efektifitas Sistem }\end{array}$ & .266 & .069 & .188 & 3.838 & .000 \\
\hline & Keuangan Desa & 1.002 & .116 & .467 & 8.615 & .000 \\
\hline
\end{tabular}

Berikutnya adalah uji statistik $\mathrm{t}$ (uji t) yang dipergunakan untuk melihat pengaruh masing-masing variabel independen terhadapvariabel dependen dengan anggapan bahwa variabel lainnya dianggap konstant (Sugiyono,2017). Bersumber pada tabel diatas dapat dilihatbahwa sistem pengendalian internal pemerintah desa $\left(X_{1}\right)$ memmiliki thitung 6,452 dan nilai signiifikansi 0,000. Thitung 6,452 > tabel1,974 dengan nilai signifikansi 0,000<0,05. Hasil 
ini menunjukkan bahwa sistem pengendalian internal pemerintah desa $\left(X_{1}\right)$ berpengaruh positiff dan signifiikan terhadap penerapan good viillage governance $(\mathrm{Y})$, maka $\mathrm{H}_{1}$ diterima.

Kompetensi sumber daya manusia $\left(X_{2}\right)$ mempunyai nilai thitung 3,838 dan nilai signifikansi 0,000 . Nilai $t_{\text {hitung }} 3,838>t_{\text {tabel }} 1,974$ dengan nilai signifikansi $0,000<0,05$. Hal ini menunjukkan bahwa kompetensi sumber daya manusia $\left(X_{2}\right)$ berpengaruh positif dan signiifikan terhadap penerapan good village goverrnance $(\mathrm{Y})$, maka $\mathrm{H}_{2}$ diterima.

Efektivitas sistem keuangan desa $\left(\mathrm{X}_{3}\right)$ mempunyai thitung 3,838 dan nilai signifikansi 0,000. thitung 8,615 $>t_{\text {tabel }} 1,974$ dengan nilai signifikansi $0,000<0,05$. Hasil ini memperlihatkan bahwa effektivitas sistem keuangan desa $\left(X_{3}\right)$ berpengaruh positif dan signifikan terhadap penerapan good village goverrnance $(\mathrm{Y})$, maka $\mathrm{H}_{3}$ diterima.

\section{Pengaruh Sistem pengendalian Internal Pemerintah Desa terhadap Penerapan Good Village Governance.}

Hasil pengujian hipotesis pada analisis regresi linier berganda mengenai pengaruh sistem pengendaliian internal pemerintah desa terhadap penerapan good village goverrnance memiliki nilai koefisien regresi 0,322 , artinya apabila sistem pengendalian internal pemerintah desa mengalami peningkatan senilai 1 satuan, maka penerapan good village governance juga akan mengalami peningkatan senilai 0,322 satuan. Sedangkan, hasil uji t mempunyai nilai signifikansi $0,000<0,05$ dan mempunyai thitung $6,452>t_{\text {tabel }}$ 1,974. Hal ini berarti bahwa sistem pengendalian internal pemerintah desa berpengaruh positif dan signifiikan terhadap penerapan good village governance.

Sistem pengendalian internal pemerintah desa memiliki pengaruh terhadap penerapan good viillage goverrnance. Sistem pengendalian yang diberlakukan secara menyeluruh pada lingkungan pemerintah desa merupakan definsi dari sistem pengendaliian internal pemerintah desa (Prawira, 2014). pengendalian internal diperlukan oleh pemerintah desa dalam upaya meningkatkan tata kelola pemerintahan desa menjadi lebih baik. Dalam hal ini perlu adanya sistem pengendalain internal dalam lingkungan pengendalian, penilaian resiko, kegiatan pengendalian, dan pemantauan dalam pengelolaan keuangan penyelenggaraan pemerintahan desa di Kabupaten Buleleng. Dengan adanya tindakan pengendalian dan pemantauan yang dilakukan pemerintah desa di Kabupaten Buleleng akan dapat mengurangi resiko terjadinya kesalahan, penyelewengan atapun penyimpangan dalam pemerintahan desa. Hal ini didukung oleh teori stewardship yang menggambarkan sifat steward yang cenderung mempertimbangkan resiko, dimana pemerintah desa sebagai steward diharapkan dapat melakukan kegiatan pegendalian dan penilaian resiko dengan mempertimbangkan resiko yang mungkin dihadapi pemerintah desa. Sehingga, dengan diberlakukanya sistem pengendalian internal desa yang baik diharapkan bisa mengendalikan penyelenggaraan kegiatan dan menjadi effektif, efisiien, transparan, akuntabel serta dapat meminimalisir terjadinya kesalahan dan penyimpangan dalam pengelolaan keuangan penyelenggaraan pemerintahan desa.

Hasil riset ini sejalan dengan hasil riset yang dilakukakan Mailoor (2017) yang menjelaskan bahwa sistem pengendalian internal pemerintah berpengaruh positif dan signifikan terhadap penerapan good goverrnance. Hasil riset ini juga sejalan dengan riset yang dilakukan oleh Kamaru (2016) yang menjelaskan sistem pengendalian internal berpengaruh positif dan signifikan terhadap penerapan good governance. Maka, dapat nyatakan bahwa sistem pengendalian internal pemerintah desa berpengaruh positif dan signifikan terhadap penerapan good village governance.

\section{Pengaruh Kompetensi Sumber Daya Manusia terhadap Penerapan Good Village Governance.}

Hasil pengujian hipotesis pada analisis regresi linier berganda mengenai pengaruh kompetensi sumber daya manusia terhadap penerapan good village governance memiliki nilai koefisien regresi 0,266 yang berarti bahwa apabila terdapat peningkatan kompetensi sumber daya manusia sebesar 1 satuan, maka penerapan good village governance juga akan meningkat 0,266 satuan. Sedangkan, hasil uji t mempunyai nilai signifiikansi $0,000<$ 
0,05 dan mempunyai nilai thitung $3,838>t_{\text {tabel }} 1,974$. hal ini menunjukkan bahwa kompetensi sumber daya manusia berpengaruh positif dan signifiikan terhadap penerapan good.

Kompetensi sumber daya manusia memiliki pengaruh terhadap penerapan good village governance. Adapun kompetensi sumber daya manusia dalam riset ini berfokus pada pengetahuan, kemampuan dan keterampilan yang dimiliki pemerintah desa dalam upaya pengelolaan keuangan desa. Teori stewardship memandang bahwa pemerintah desa sebagai pihak yang dapat dipercaya, berintegritas tinggi, mampu bertindak dengan penuh tanggungjawab dan mampu berprilaku dengan baik untuk kepentingan masyarakat. Dalam hal ini pemerintah desa di Kabupaten Buleleng diharapkan dapat bekerja dengan optimal untuk kepentingan publik dengan demikian akan dapat memberikan pelayanan yang baik pada masyarakat dan dapat membuat pertanggungjawaban yang diamanahkan kepadanya. Untuk melaksanakan tanggungjawab tersebut pemerintah desa diharapkan dapat mengerahkan semua kemampuan dan kompetensi yang dimilikinya. Dalam pemerintahan desa diperlukanya kompetensi sumber daya manusia agar dapat menerapkan tata kelola pemerintahan yang baik. Sumber daya manusia yang kompeten sangat diperlukan dalam pemerintah desa agar pengelolaan keuangan desa bisa dipertangungjawabkan secara transparan dan akuntabel. Kompetensi sumber daya manusia yang memadai diharapkan dapat mendukung pengelolaan keuangan desa mulai dari tahap perencanaan, pelaksanaan, penatausahaan, pelaporan dan pertanggujawaban, sehingga keuangan desa dapat dialokasikan dengan benar tepat waktu, transparan, partisipatif dan akuntabel. Oleh karena itu diperlukannya sumber daya manusia yang berkompeten dalam pemerintahan desa karena kompetensi sumber daya manusia menjadi elemen yang berpengaruh dalam menentukan keberhasilan pemerintah desa dalam menerapkan good village governance.

Hasil riset ini sejalan dengan hasil riset yang dilakukan oleh Helmayani (2017) menjelaskan bahwa kompetensi sumber daya manusia berpengaruh positif dan signifikan terhadap implementasi good village governance. Dengan demikian, dapat dinyatakan bahwa kompetensi sumber daya manusia berpengaruh positif dan signifikan terhadap penerapan good village governance.

\section{Pengaruh Efektivitas Sistem Keuangan Desa terhadap Penerapan Good Village Governance.}

Hasil pengujian hipotesis pada analisis regresi linier berganda mengenai pengaruh efektivitas sistem keuangan desa terhadap penerapan good village governance memiliki nilai koefisien regresi 1,002 yang berarti bahwa apabila terjadi peningkatan efektivitas sistem keuangan desa sebesar 1 satuan, maka penerapan good village governance juga akan meningkat sebesar 1,002 satuan. Sedangkan, hasil uji t mempunyai nilai signifikansi sebesar $0,000<0,05$ dan mempunyai nilai $t_{\text {hitung }} 8,615>t_{\text {tabel }} 1,974$. hal ini menunjukkan bahwa efektivitas sistem keuangan desa berpengaruh positif dan signifikan terhadap penerapan good village governance.

Efektivitas sistem keuangan memiliki pengaruh terhadap penerapan good village governance. Sistem keuangan desa berperan guna meningkatkan kualitas tata kelola keuangan desa. Pemberian dana yang jumlahnya begitu besar ke desa akan berbanding lurus juga dengan tanggungjawab pemerintah yang semakin bertambah, dimana pemerintah desa diharapkan mampu menerapkan prinsip akuntabiliitas dan transparansi dalam pengelolaan keuangan desa, serta setiap kegiatan yang diselenggarakan pemerintah desa harus dapat dipertanggungjawabkan kepada masyarakat desa. Sistem keuangan desa dapat memudahkan pemerintah desa dalam proses pengelolaan keuangan, membantu dalam proses menginput data, mencarian data dan membuat laporan keuangan desa, sehingga sistem keuangan desa dapat meminilimalisasi terjadinya kesalahan dan keamanan data dapat dijaga secara optimal (Rusmayanti dkk., 2010). Sistem keuangan desa berperan dalam mewujudkan akuntabilitas, dengan sekali input sistem keuangan desa dapat menghasilkan dokumen penatausahan dan berbagai laporan yang sudah sesuai dengan ketentuan yang berlaku dan pelaporan keuangan desa menjadi tepat waktu dan akurat. Efektivitas sistem keuangan desa akan dapat meningkatkan akuntabilitas, transparansi dan disiplin anggaran dalam pengelolaan keuangan desa. Dengan demikian, 
effektivitas sistem keuangan desa berperan penting dalam penerapan tata kelola pemerintahan yang baik (good village governance).

Hasil riset ini sejalan dengan hasil riset yang dilakukan oleh Krisnawati (2019) yang menjelaskan bahwa efektivitas sistem keuangan desa berpengaruh positif dan signifikan terhadap kinerja pemerintah desa. Hasil riset Saputri (2019) menjelaskan bahwa sistem keuangan memiliki pengaruh terhadap good village governance. Dengan demikian, dapat dinyatakan bahwa efektivitas sistem keuangan desa berpengaruh positif dan signifikan terhadap penerapan good village governance.

\section{Simpulan Dan Saran}

Berdasarkan hasil penelitian simpulan dalam penelitian ini, pertama, sistem pengendalian internal pemerintah desa berpengaruh positif dan signifikan terhadap penerapan good village governance dengan nilai thitung 6,452 $>t_{\text {tabel }} 1,974$ dan nilai signifikansi $0,000<0,05$. Hal ini berarti bahwa sistem pengendalian internal pemerintah desa yang baik akan meningkatkan penerapan good village governance. Kedua, kompetensi sumber daya manusia berpengaruh postif dan signifikan terhadap penerapan good village governance dengan nilai thitung $3,838>t_{\text {tabel }} 1,974$ dan nilai signifikansi $0,000<0,05$. Hal ini berarti bahwa kompetensi sumber daya manusia yang baik akan meningkatkan penerapan good village governance. Ketiga, Efektivitas sistem keuangan desa berpengaruh positif dan signifikan terhadap penerapan good village governance dengan nilai thitung $8,615>t_{\text {tabel }} 1,974$ dan nilai signifikansi $0,000<0,05$. Hal ini berarti bahwa efektivitas sistem keuangan desa akan meningkatkan penerapan good village governance.

Peneliti menyarankan pertama, bagi pemerintah desa diharapkan dapat meningkatkan sistem pengendalian internal pemerintah desa untuk meminimalisir terjadinya kesalahan dan penyimpangan dalam penyelenggaraan pemerintahan desa. Kedua, diharapkan agar pemerintah desa mengoptimalkan kompetensi sumber daya manusia yang dimilikinya dan meningkatkan efektivitas penggunaan sistem keuangan desa agar dapat meningkatkan pengelolaan keuangan desa menjadi lebih effektif dan efisien serta dapat dipertangungjawabkan secara transparan dan akuntabel. Ketiga, bagi peneliti selanjutnya yang tertarik melakukan riset yang sejenis diharapkan agar menggunakan variabel lain yang juga menjadi faktor-faktor yang mempengaruhi penerapan good village governance.

\section{Daftar Pustaka}

Daniri. 2005. Good Corporate Governance: Konsep dan Penerapannya dalam Konteks Indonesia. Jakarta: Ray Indonesia.

Helmayani, Putu Lia. 2017. Pengaruh Kompetensi Sumber Daya Manusia, Peran Badan Permusyawaratan Desa, dan Partisipasi Masyarakat Terhadap Implementasi Good Village Governance (Studi Pada Desa di Kabupaten Buleleng). Skripsi. Jurusan Akuntansi Program S1. Universitas Pendidikan Ganesha.

Ishanti, Emilda. 2014. Pengaruh Kompetensi Sumber Daya Manusia dan Penerapan Sistem Akuntansi Keuangan Daerah Terhadap Kualitas Laporan Keuangan Daerah (Studi Empiris pada SKPD Kabupaten Lima Puluh Kota). Artikel. Universitas Negeri Padang.

Kamaru, Brully. 2016. Pengaruh Sistem Pengendalian Internal Pemerintah Terhadap Good Governance Pemerintah Kabupaten Bone Bolango. Skripsi. Universitas Negeri Gorontalo.

Krisnawati, Ni Made Gita. 2019. Pengaruh Efektivitas Sistem Keuangan Desa (Siskeudes) dan Kompetensi Sumber Daya Manusia Terhadap Kinerja Pemerintah Desa (Studi Pada Desa Di Kecamatan Kediri Kabupaten Tabanan). Skripsi. Jurusan Akuntansi Program S1. Universitas Pendidikan Ganesha.

Mailoor, Jefri Herbert, Jullie J Sondakh. 2017. Pengaruh Sistem Akuntansi pemerintah, Budaya Organisasi, Kinerja Aparatur Pemerintah Daerah, peran APIP, dan Sistem 
Pengendalian Internal Pemerintah Terhadap Penerapan Good Governance (Studi Empiris Di Kabuapaten Talaud). Jurnal Riset Akuntansi dan Auditing. Vol. 8, No. 2: 8294.

Peraturan Pemerintah Nomor 32 tahun 2004 tentang Pemerintah Daerah. Lembaran Negara Republik Indonesia Tahun 2004. Jakarta: Sekretariat Negara.

Prawira, I.M. 2014. Pengaruh Moralitas Individu, Asimetri Informasi, dan Efektivitas Pengendalian Terhadap Fraud (Kecurangan) Akuntansi (Studi Empiris pada Badan Usaha Milik Desa Kabupaten Buleleng). Skripsi. Universitas Pendidikan Ganesha.

Rusmayanti, A., Purnama, B., \& Sukadi. 2010. Sistem Informasi Pengelolaan Keuangan. Indonesi Journal On Science, 1-5.

Saputri, Nikita Aprilia. 2019. Analisis Penerapan Sistem Keuangan Desa (Siskeudes) Sebagai Terciptanya Good Village Governance (Studi Kasus Pada Desa Banjarejo, Kecamatan Donomulyo, Kabupaten Malang, Jawa Timur). Malang: Universitas Muhammadiyah Malang.

Solekhan, Moch. 2012. Penyelenggaraan pemerintahan desa berbasis partisipasi masyarakat dalam membangun mekanisme akuntabilitas. Malang: Setara press

Sugiyono. 2013. Metode Penelitian Kualitatif Kuantitaif dan $R \& D 12^{\text {th }}$ Edition. Bandung: CV Alfabeta.

Sulina, I Gusti Ayu Trisha. 2018. Peranan Sistem Keuangan Desa (Siskeudes) Terhadap Kinerja Pemerintah Desa (Studi Kasus Di Desa Kaba-Kaba Kecamatan Kediri Tabanan). Skripsi. Universitas Pendidikan Ganesha.

Undang-Undang Nomor 6 Tahun 2014 tentang Desa. Lembaran Negara Republik Indonesia Tahun 2014. Jakarta: Sekretariat Negara. 